\title{
The Transparency Theory: An Alternative Approach to Glass-Steagall Issues
}

\author{
Michael S. Raab
}

Commercial banks play a central role in our economy, ${ }^{1}$ and a complex regulatory system has evolved to monitor their activities. ${ }^{2}$ Among the most controversial components of this system is the Glass-Steagall Act, ${ }^{\mathbf{3}}$ which

1. See Reform of the Nation's Banking and Financial Systems: Hearings Before the Subcomm. on Financial Institutions Supervision, Regulation and Insurance of the House Comm. on Banking, Finance and Urban Affairs, 100th Cong., 1st Sess. 10 (1987) (statement of L. William Seidman, Chairman, Federal Deposit Insurance Corporation) ("[A]ny threat to the banking system is a threat to consumer services and savings, the intermediation process, private sector liquidity, the payment system and, most importantly, the U.S. economy.").

2. Responsibility for regulating the country's more than 14,000 commercial banks is divided among the Office of the Comptroller of the Currency (OCC), the Federal Reserve Board, the Federal Deposit Insurance Corporation (FDIC), state banking agencies, the Securities and Exchange Commission (SEC), and the Department of Justice. The OCC regulates banks with charters issued by the federal government ("national banks"). Banks with state-issued charters that are members of the Federal Reserve System (state "member" banks) are regulated by the Federal Reserve Board and their state regulatory agency. State-chartered banks that are not members of the Federal Reserve System (state "non-member" banks) are regulated by their state regulator and, if they are federally insured, by the FDIC. See Task Group on Regulation of Financial Services, Blueprint for Reform: The Report of the Task Group on Regulation of Financial Services 16, 18-20 (1984).

Most commercial banks are insured by the FDIC. Insurance is required for national and state member banks. State non-member banks, however, are not required to have deposit insurance. Id. at 18 n.6.

In addition to regulation of the bank itself, a separate layer of regulation exists for the parent holding companies of banks. The Federal Reserve Board regulates all bank holding companies in the United States, regardless of whether the Board regulates the holding company's banking subsidiary. Id. at 20.

3. 12 U.S.C. $\$ \S 24$ (Seventh), 78, 377-378 (1982 \& Supp. IV 1986). The Glass-Steagall Act was enacted as part of the Banking Act of 1933. The Glass-Steagall provisions make up only four of the 34 sections of the Banking Act: sections 16, 20,21, and 32. Section 16 limits the securities business of national banks to purchasing and selling securities for customers. Id. $\S 24$ (Seventh). This section, however, sets forth several exceptions to its general prohibition on bank underwriting and dealing. Thus, banks may underwrite and deal in the following "bank-eligible" securities: obligations of the United States government; general obligations of any state or political subdivision; obligations, participations, or other instruments of, or issued by, the Federal National Mortgage Association (FNMA) or the Government National Mortgage Association (GNMA); obligations issued under authority of the Federal Farm Loan Act; obligations issued by the Federal Home Loan banks; and obligations or other securities of the Student Loan Marketing Association. Id. $\$ 24$ (Seventh). Section 20 prohibits a Federal Reserve System member bank from affiliating (i.e.; sharing the same parent holding company) with an investment banking firm. Id. $\S 377$. Section 21 forbids any person or entity engaged in the business of issuing, underwriting, selling, or distributing securities from accepting bank deposits. Id. $\S 378$. Section 32 prohibits any officer, director, or employee of an investment banking firm from serving at the same time as an officer, director, or employee of any Federal Reserve System member bank. Id. $§ 78$. 
generally prohibits commercial banks from underwriting and dealing in securities. ${ }^{4}$

Since the enactment of Glass-Steagall in 1933, financial markets and the regulatory framework controlling them have changed, bringing commercial banks increasingly into competition with other firms offering financial services. The advent of instruments such as commercial paper has deprived banks of some of their safest lending opportunities. ${ }^{5}$ Increased competition from foreign lenders ${ }^{8}$ and from non-bank institutions ${ }^{7}$ has also had a significant impact on the profitability of U.S. banks. ${ }^{8}$ As profit-

4. But see Golembe, The Glass-Steagall Act-Friend or Foe?, 2 GolemBE REP. 3-5 (1987) (arguing that Glass-Steagall is mischaracterized as a prohibitory statute; rather, it is, and always was intended to be, a regulatory statute permitting banks to engage in substantial securities activities); Modernization of the Glass-Steagall Act: Hearing Before the Senate Comm. on Banking, Housing, and Urban Affairs, 100th Cong., 1st Sess. 67 (1987) [hereinafter Hearings] (statement of Edward J. Kelly III, on behalf of J.P. Morgan \& Co.) (making argument similar to Golembe and noting that in 1935 , just two years after the enactment of Glass-Steagall, Senator Carter Glass, the primary author of Glass-Steagall, supported proposal to permit national and state member banks (as opposed to their affiliates) to underwrite investment securities).

5. "Commercial paper" generally refers to promissory notes issued by corporations to raise shortterm capital. Such notes usually have maturity dates of less than nine months. See Norton, $U p$ Against "The Wall": Glass-Steagall and the Dilemma of a Deregulated ("Reregulated") Banking Environment, 42 Bus. LAw. 327, 343 (1987). Today, most large, reputable corporations find it less costly to raise short-term capital by issuing commercial paper rather than by borrowing from banks. Between 1975 and 1985, the share of bank loans as a source of short-term corporate debt for large manufacturing firms dropped from nearly $50 \%$ to less than $25 \%$. Statement of Thomas C. Theobald, Vice Chairman, Citicorp, Before the Board of Governors of the Federal Reserve System 2 (Feb. 3, 1987) (on file with author) [hereinafter Statement of Thomas C. Theobald]. A Securities Industry Association economist has estimated that investment bankers placed $\$ 992.4$ billion of commercial paper in 1986, more than three times the amount placed in 1980. Statement of Jeffrey M. Schaeffer, Ph.D, Senior Vice President and Director of Research, Securities Industry Association, Before the Board of Governors of the Federal Reserve System 8 (Feb. 3, 1987) (on file with author).

6. See Hearings, supra note 4, at 143 (statement of Thomas S. Johnson, President, Chemical Bank); Memorandum of the New York Clearing House Association Before the Board of Governors of the Federal Reserve System 21 (Jan. 29, 1987) (on file with author) ("New York's premier position [as the leading financial center] is threatened by the emergence of Tokyo and the revitalization of London as financial centers.")

In 1970, nine of the 25 , and seven of the ten, largest banks in the world were U.S. banks. In 1986, only three of the 25 , and two of the ten, largest banks were U.S. banks. Id. at 22. In 1946, U.S. commercial banks held 57\% of the nation's financial assets. By 1985, however, U.S. banks held just $33 \%$ of these assets. Litan, Taking the Danger Out of Bank Deregulation, Brookings REv., Fall 1986 , at 3.

7. See Note, Restrictions on Bank Underwriting of Corporate Securities: A Proposal for More Permissive Regulation, 97 HARv. L. REv. 720 (1984). The growth of money market mutual funds has forced banks to increase the interest rates that they must pay to attract deposits. Id. at 720 n. 2 . Moreover, finance companies owned by such commercial giants as Sears and General Motors have taken away many consumer lending opportunities from banks. Id. at 720 n.3.

8. The profitability of U.S. banks has declined significantly. Between 1979 and 1984, the banking industry's return on equity dropped from $14.3 \%$ to $10.7 \%$. Litan, supra note 6 , at 8 . Between 1979 and 1983, the after-tax return on equity for the ten largest bank holding companies dropped from $16 \%$ to 13\%. J.P. Morgan \& Co., Rethinking Glass-Stengall 20 (1984). During the same period, the after-tax return on equity for large investment banks increased from $19 \%$ to $24 \%$. Id.

Assuring that banks are profitable is vital to maintaining a healthy economy. When banks experience financial difficulty, the consequences can be considerably greater than when a commercial entity fails. When corporations fail, the ripple effects are generally limited geographically or to a particular sector of the economy. Litan, supra note 6, at 3,5. Smooth operation of the banking system, however, depends heavily on maintaining the confidence of depositors in the safety of their banks. When one bank experiences financial difficulty, the confidence of depositors at healthy institutions can diminish as well, resulting in large-scale withdrawals of deposits at all banks. Id. at 5 . 
ability has declined, bank failures have risen:9 This is reason for concern, because a healthy banking system is necessary for the economy to operate smoothly. ${ }^{10}$ Banks, therefore, should be permitted to engage in activities that will improve their financial position as long as the investing public is adequately protected.

The extent to which banks can, and should be permitted to, underwrite and deal in securities has recently been considered by Congress, ${ }^{11}$ the judiciary, ${ }^{12}$ and bank regulators. ${ }^{13}$ Several commentators have convincingly argued that Glass-Steagall should be repealed. ${ }^{14}$ This Note argues that if Glass-Steagall is not repealed, ${ }^{15}$ the Act should be interpreted to allow banks to underwrite and deal in securities backed by their own assets. Such "securitization" would not conflict with any of the purposes of Glass-Steagall and would enable banks to increase the liquidity of their assets and remain competitive in today's increasingly volatile financial markets. ${ }^{18}$

9. See Bock, Bleak Year for the Banks, TiME, Dec. 28, 1987, at 60 .

10. See supra note 1 ; see also supra note 8 .

11. On March 30,1988, the Senate passed S.1886, a bill that would give banks immediate authority to underwrite and deal in municipal revenue bonds, and, through separately incorporated affiliates, commercial paper, mortgage-backed securities and securities backed by consumer debt. Six months after passage, such affiliates would be allowed to underwrite corporate debt and mutual funds. See Nash, Key Banking Bill Passed by Senate, N.Y. Times, Mar. 31, 1988, at A1, col. 6, D6, col. 3.

The bill is expected to face substantial opposition in the House. Id. Representative Fernand St Germain, Chairman of the House Banking Committee, recently released a draft of proposed legislation that would give banks significantly fewer securities powers. See Nash, Bill in House Would Limit Bank' Underwriting Power, N.Y. Times, Mar. 24, 1988, at D13, col. 1.

12. See Securities Indus. Ass'n v. Board of Governors, 839 F.2d 47 (2d Cir. 1988) (approving, to a limited extent, applications of three large commercial banks, Bankers Trust, Giticorp, and J.P. Morgan, to engage through wholly-owned subsidiaries in the underwriting of, and dealing in, commercial paper, mortgage-backed securities, municipal revenue bonds, and securities backed by consumer loans), petition for cert. filed, 56 U.S.L.W. 3667 (U.S. Mar. 12, 1988) (No. 87-1513).

13. Banks and bank holding companies have been seeking from federal bank regulators additional powers to deal in and underwrite securities. New York state regulators recently interpreted their own state law version of Glass-Steagall to allow state-chartered banks to engage in a substantial amount of securities underwriting through separate subsidiaries. Andrews, Does Glass-Steagall Matter Anymore?, INSTITUTIONAL INVESTOR, May 1987, at 175.

14. See R. Litan, What Should Banks Do? 60-72 (1987); Deregulating Wall Street (I. Walter ed. 1985); J.P. MORGAN \& Co., supra note 8; Note, supra note 7; Isaac, The Real Reason Glass-Steagall Still Survives, Am. Banker, Apr. 23, 1987, at 4-5, col. 1. But see Securities Indus. Ass'n, Public Policy Issues Raised by Bank Securities Activities, 20 San Diego L. Rev. 339 (1983).

15. See supra note 11. Efforts to repeal Glass-Steagall are likely to meet with vigorous opposition from the securities industry. The securities industry's lobbying power is well known and is evidenced most recently by the moratorium on bank securities powers included in the Competitive Equality Banking Act of 1987. See Corwin, A Banker's Guide to the Moratorium, ABA BANKING J., Oct. 1987, at 73. See also Isaac, supra note 14, at 5 (quoting Senator William Proxmire, Chairman of the Senate Committee on Banking, Housing, and Urban Affairs, as saying that "the other side [the securities industry] has more of the green ... They make big contributions to the campaigns."; noting that, since 1981, Senator Alfonse D'Amato, formerly chairman of the Senate Banking Suboommittee on Securities, has received more than $\$ 500,000$ from "the partners, executives, and political action committees of Wall Street firms."); Shaw, Better Luck in Washington, BANKERS MAG., July-Aug. 1987, at 55 (emphasizing banking industry's inability to organize and develop effective government relations program); Andrews, supra note 13, at 178 (quoting a Washington bank consultant: "The banks don't know how to lobby. They are cheap, and they don't respect the vagaries of the political process.' ").

16. See Pavel, Securitization, Econ. PersP., July-Aug. 1986, at 16. 
Section I of the Note examines the current debate over the purposes behind the Glass-Steagall Act. Section II summarizes the recent limited approval by the Office of the Comptroller of the Currency (OCC) of bank underwriting of mortgage-backed securities and explains the "transparency theory"17 that underlies this approval. Section III argues that application of the transparency theory should be expanded to permit banks to securitize and sell their mortgage loans and other assets. This Section demonstrates that adequate controls can be set up to prevent banks from using these additional securities powers to effectively enter into the general business of securities underwriting for third parties in violation of Glass-Steagall. Section IV shows that allowing banks these additional securities powers would not give rise to many of the dangers that GlassSteagall was designed to prevent and that regulation could effectively address those dangers that might arise.

\section{The Purposes of the Glass-Steagall Act}

Until recently, most commentators assumed that the Glass-Steagall Act was enacted in order to promote public confidence in the banking system and to eliminate the conflicts of interest that may arise when commercial banks engage in securities activities. ${ }^{18}$ These goals, however, could have been accomplished as effectively through regulation as by the prohibitory approach used in Glass-Steagall. ${ }^{18}$ Thus, some scholars have argued that the Act is best understood as a private-interest group statute conferring a benefit-freedom from competition from commercial banks-on investment bankers. ${ }^{20}$

Professor Langevoort has recently challenged this characterization. Langevoort convincingly argues that Glass-Steagall is a public-interest statute designed to eliminate the incentive of banks to use funds for speculative purposes, rather than for traditional commercial lending activities. ${ }^{21}$ The historical record surrounding the enactment of Glass-Steagall suggests that Senator Garter Glass, the primary author of the Act, believed that the best way to ensure the banking system's stability was to prevent banks from engaging in non-traditional activities, such as making loans to

17. See infra notes 29-30 and accompanying text.

18. See, e.g., Kelly, Conflicts of Interest: A Legal View, in Deregulating Wal.. Street supra note 14, at 231; Note, supra note 7, at 721-22; Note, $A$ Conduct-Oriented Approach to the GlassSteagall Act, 91 YALE L.J. 102, 102-03 (1981) [hereinafter Note, Conduct-Oriented Approach].

19. See Langevoort, Statutory Obsolescence and the Judicial Process: The Revisionist Role of the Courts in Federal Banking Regulation, 85 MICH. L. REv. 672, 690-91 (1987).

20. See, e.g., Benston, Federal Regulation of Banking: Analysis and Policy Recommendations, 13 J. BAnk Res. 216, 222 (1983); Macey, Promoting Public-Regarding Legislation Through Statutory Interpretation: An Interest Group Model, 86 ColuM. L. REv. 223, 237 (1986); Macey, Special Interest Groups Legislation and the Judicial Function: The Dilemma of Glass-Steagall, 33 EMORY L.J. 1, 15-21 (1984).

21. Langevoort, supra note 19, at 697. 
fund the purchase of securities. ${ }^{22}$ Glass thought that smooth operation of the banking system would be achieved if banks concentrated on their traditional role as financial intermediary between depositors and shortterm commercial borrowers. ${ }^{23}$ The prohibition of bank underwriting and dealing contained in Glass-Steagall can be attributed to Senator Glass' apparent desire to ensure that banks did not become involved in speculative activities. The concerns about conflicts of interest and depositor confidence traditionally emphasized by commmentators ${ }^{24}$ and courts ${ }^{25}$ were subordinate to this larger objective and can be adequately addressed through regulation. ${ }^{28}$

\section{The OCC's Use of the Transparency Theory}

The $\mathrm{OCC}^{27}$ has authorized national banks to act as principals in the purchase and sale of securities representing interests in, or secured by, pools of federally insured mortgages. ${ }^{28}$ The basis for these OCG decisions

22. Id. See also Bishop, Questions the Bank Bill Raises, NAtion's Bus., Aug. 1933, at 46, 64; Deposit Insurance, Bus. Wk., Apr. 12, 1933, at 3 ("His [Senator Glass'] whole idea is to get the bankers back into the banking business.").

23. Langevoort, supra note 19 , at 697 . Senator Glass believed that if commercial banks engaged primarily in short-term commercial lending, the money supply would be "subject to a natural discipline." Id. at 693. This theory was known as the "real bills doctrine." While popular during the early part of this century, it has since been discredited. See Humphrey, The Real Bills Doctrine, FeD. Reserve BanK of Richmond Econ. Rev., Sept.-Oct. 1982, at 3.

24. See, e.g., Note, Conduct-Oriented Approach, supra note 18, at 103 ("Congress enacted the Glass-Steagall Act for two purposes. First, and most importantly, it sought to eliminate the conflicts of interest that arise when commercial banks engage in the sale of securities. Second, it sought to prevent loss of public confidence in the banking system, which had led to runs on banks and to bank failures at the start of the Great Depression.")

25. See, e.g., Investment Co. Inst. v. Camp, 401 U.S. 617 (1971). The issue in Camp was the permissibility of a plan by First National City Bank to establish and market to the general public a collective investment fund. The Court held that, while none of City Bank's capital would be placed at risk (since the bank would only be involved in managing investment funds of third parties), the fund presented a number of more "subtle hazards" (i.e., conflicts of interest and confidence concerns) which Congress sought to prevent in enacting Glass-Steagall. Id. at 630-33.

26. Langevoort, supra note 19 , at 699,714 ("In fact, it is likely that had they [the conflict of interest and confidence concerns] been Congress' only fears-had Congress considered securities activities a proper part of the business of banking-they would have been dealt with by regulation rather than divorce.").

27. See supra note 2 for a discussion of the roles of the OCC and the other primary bank regulators.

28. See, e.g., Letter from Brian W. Smith, Chief Counsel of the OCC (Apr. 12, 1983), reprinted in [1983-1984 Transfer Binder] Fed. Banking L. Rep. (CCH) I 85,421, at 77,544 (granting approval for bank's sale of pass-through certificates backed by Federal Housing Association (FHA)-insured mortgages purchased by the bank from GNMA, noting that pool of FHA-insured loans is "legally transparent" and that the certificates are therefore indistinguishable from the underlying loans); Letter from Robert L. Clarke, Comptroller of the Currency, to Russell A. Freeman (June 16, 1987), at 10-11 (on file with author) (approving Security Pacific National Bank's sale of pass-through certificates backed by a pool of bank's conventional mortgage loans and noting that OCC does not believe "that the pooling and packaging of these assets alters the fundamental character of the transaction so as to create a security within the meaning of Glass-Steagall.") [hereinafter Clarke Letter]; Letter from Richard V. Fitzgerald, Chief Counsel of the Comptroller of the Currency, to Robert Tortoriello (May 22,1986 ) (on file with author) (approving Liberty Norstar Bank's proposal to underwrite and deal in collateralized mortgage obligations (CMOs) backed by pools including conventional mortgage loans and/or certificates approved by GNMA, FNMA, or the Federal Home Loan Mortgage Corporation 
has been the notion that such securities are "legally transparent," the holders of the securities have essentially the same rights, liabilities, and risks as if they were the direct owners of the underlying mortgage loans. Thus, banks may underwrite and deal in mortgage-backed securities only to the extent that they may underwrite and deal in the underlying mortgage loans. According to this "transparency theory," these instruments are, for Glass-Steagall and other banking law purposes, the functional equivalent of the collateral securing them. The distinction between certificates representing interests in a pool of mortgages and the underlying mortgage obligations thus has no legal relevance. ${ }^{30}$ The OCC has concluded that if a national bank is authorized to issue, underwrite, or deal in the collateral underlying a mortgage-backed security, the bank is not required to obtain separate authorization to issue, underwrite, or deal in the security.

The Securities Industry Association (SIA) ${ }^{31}$ has argued that bank issuance of mortgage-backed securities violates the prohibitions of GlassSteagall. ${ }^{32}$ However, in its recent approval of Security Pacific National Bank's sale of mortgage-backed pass-through certificates, ${ }^{33}$ the OCC re-

(FHLMG)) [hereinafter Fitzgerald Letter]; Letter from Robert L. Clarke, Comptroller of the Currency, to Senator Alfonse M. D'Amato (June 18, 1986) (on file with author) (discussing Liberty Norstar transaction); Letter and Press Release from Robert Bloom, Acting Comptroller of the Currency, to Leland S. Prussia (Mar. 29-30, 1977), reprinted in [1973-1978 Transfer Binder] Fed. Banking L. Rep. (CCH) I 97,093 (approving issue by Bank of America of securities backed by residential mortgage portfolio) [hereinafter Bloom Letter]. Federally insured mortgages are mortgages that are insured against the risk of default by the FHA or by the Veterans Administration (VA). This insurance reduces the risk borne by savings and loans and other mortgage originators and thus increases the availability of funds for the purchase of housing. See A. AXELROD, C. BERGER \& Q. Johnstone, Land Transfer and Finance 112-13 (3d ed. 1986); Murray \& Hadaway, MortgageBacked Securities: An Investigation of Legal and Financial Issues, 11 J. CoRP. L. 203, 205 (1986). The volume of privately issued mortgage-related securities has grown from about $\$ 1$ billion in 1982 to nearly $\$ 57$ billion in 1986. Statement of Thomas C. Theobald, supra note 5 .

29. Clarke Letter, supra note 28 , at 11.

30. Id. See also Fitzgerald Letter, supra note 28; Bloom Letter, supra note 28.

31. The SIA is a national trade association which represents more than 500 investment banking firms. Complaint for Declaratory and Injunctive Relief at 2, Securities Indus. Ass'n v. Clarke, No. 87 Civ. 4504 (KTD) (S.D.N.Y. filed June 25, 1987). These firms are responsible for over 90 percent of the brokerage and investment banking business in the United States. Id.

32. Clarke Letter, supra note 28 , at 5 . It has been suggested that the investment bankers are opposed to broadening the securities powers of banks because this would increase competition in the market for investment banking services and thus reduce profits for securities firms. See Isaac, supra note 14 , at 5 .

33. Clarke Letter, supra note 28, at 5. The SIA has sought judicial review of this order. Securities Indus. Ass'n v. Clarke, No. 87 Civ. 4504 (KTD) (S.D.N.Y. filed June 25, 1987).

There are three basic types of mortgage-backed securities: pass-throughs, mortgage-backed bonds, and pay-throughs. A pass-through certificate represents direct ownership in a portfolio of mortgage loans that are similar in interest rate, quality, and term to maturity. The portfolio is placed in a trust, and certificates of ownership are sold to investors. The loan originator services the mortgage portfolio and collects interest and principal, passing on these amounts, less a servicing fee, to the investors. Pavel, supra note 16, at 15-16. Mortgage-backed bonds are also collateralized by a portfolio of mortgages. Id. at 16-17. Unlike the pass-through, however, mortgage-backed bonds are debt obligations of the issuer. As a result, the portfolio of mortgages which are used as collateral remain on the issuer's books as assets and the bonds are considered liabilities. In addition, the cash flows from the collateral are not used for the payment of principal and interest on the bonds. The bonds have a stated maturity, generally between five and twelve years, and interest is usually paid semiannually. Id. at 18. Like 
jected the SIA's arguments. The OCC held that the mortgage-backed certificates were not "securities" within the meaning of Glass-Steagall. ${ }^{\text {s4 }}$ Rather, sale of the certificates merely represented a sale of the bank's own assets, since the certificate holders had essentially the same rights, liabilities, and risks as if they owned the underlying assets.

Even assuming that the certificates were securities within the meaning of Glass-Steagall, the OCC held that the proposed issuance by Security Pacific would not violate the prohibitions of either section 16 or section 21 of the Act. Section 16 permits a bank to deal in securities and stock, but only if such dealing is "limited to purchasing and selling such securities and stock without recourse, solely upon the order, and for the account of, customers, and in no case for its own account. . . ."3s Section 16 also provides that banks "shall not underwrite any issue of securities or stock." Section 21 prohibits any organization "engaged in the business of issuing, underwriting, selling, or distributing . $\therefore$ securities" from engaging at the same time in the business of receiving deposits. ${ }^{37}$ The OGC noted that "underwriting" refers to the process of purchasing another company's newly issued securities for distribution and sale to investors and that "dealing" involves the purchase and sale of another company's securities in the secondary market. Since Security Pacific wanted only to participate in the initial sale of instruments backed by its own mortgage loans, the OCC held that the proposed transaction involved neither "underwriting" nor "dealing."ss

mortgage-backed bonds, pay-through bonds are collateralized by mortgage loans and appear on the issuer's books as debt. The cash flows from the underlying mortgages, however, are used to service the bonds in a manner similar to that of pass-throughs. One common type of pay-through bond is known as the collateralized mortgage obligation (CMO) and was first issued in June 1983. CMO issues are divided into maturity classes (usually four). Each class receives semiannual interest payments. Class 1 bondholders receive the first installments of principal payments and any prepayments until Class 1 bonds are paid off. Class 2 bondholders, in turn, receive principal payments and prepayments before Class 3 bondholders are paid off. Class 3 bondholders are paid off next, followed by those in Class 4 . The use of this class structure makes the term of the securities more certain. Thus, CMOs mitigate the risk of prepayment (i.e., the risk that a borrower will repay the principal amount of the loan earlier than schedule) for those who hold bonds in classes 3 and 4 , since any prepayments are first paid to the earlier classes of bondholders. CMOs also provide shorter maturity classes of mortgage securities (classes 1 and 2). Thus, investors who might not have otherwise invested in mortgages (i.e., those concerned with prepayment risk and those desiring shorter maturity periods) have entered the mortgage securities market. As a result, CMOs have become quite popular. Id. at 19.

34. Clarke Letter, supra note 28 , at 10-11.

35. 12 U.S.C. \& 24 (Seventh) (Supp. IV 1986).

36. Id.

37. 12 U.S.C. $\$ 378$ (1982).

38. Clarke Letter, supra note 28, at 12-13. To support its holding in the Security Pacific transaction, the OCC also relied in part on additional language in section 21 which states that "nothing in this paragraph shall be construed as affecting in any way such right as any bank ... may otherwise possess to sell, without recourse or agreement to repurchase, obligations evidencing loans on real estate." 12 U.S.C. $\$ 378(a)(1)$ (1982). This language reflects a congressional desire to leave the secondary market for mortgage loans undisturbed. See Clarke Letter, supra note 28, at 18. 


\section{Expanding the Application of the Transparency Theory}

The approach used by the OCC in the Security Pacific transaction is typical of most courts and bank regulatory agencies confronted with Glass-Steagall issues. Courts usually focus on the language of the statute to determine whether a proposed activity involves a "security" and, if so, whether the proposed activity constitutes "underwriting" or "dealing."38 Under Professor Langevoort's approach, a court would permit any securities activity that would not divert bank funds to speculative uses. ${ }^{40}$ According to Langevoort, his approach, like the transparency theory, would permit banks to securitize and sell their own assets, since this would merely assist banks in performing their traditional role as intermediary between net savers and net borrowers. ${ }^{11}$ Adoption of Langevoort's approach, however, would force courts to change their method of analyzing Glass-Steagall issues. Rather than focusing on the meaning of such terms as "security," "underwriting," and "dealing," courts would have to determine whether a proposed activity would take banks out of their traditional role as intermediary between depositors and commercial borrowers.

It is uncertain whether, in applying Professor Langevoort's approach, courts would reach results consistent with his desires. Determining whether a securities activity of a bank is "speculative" is no easy task for courts that are unfamiliar with the intricacies of banking law. ${ }^{42}$ Judges are generally not proficient at construing complex economic statutes like Glass-Steagall. ${ }^{43}$ The transparency theory requires courts to determine only whether the collateral underlying the instrument to be underwritten is a bank asset. By charging the courts with this more manageable inquiry, the transparency theory ensures results which are consistent with the purposes of Glass-Steagall.

This Note proposes expanding the application of the transparency theory to permit banks to underwrite and deal in securities backed by any of their own assets. In the Security Pacific transaction discussed in Section II, the OGC emphasized that the proposed securities issuance represented merely a sale of Security Pacific's own assets (in that case, mortgage loans) which involved neither "securities" nor "underwriting" or "deal-

39. See Note, Conduct-Oriented Approach, supra note 18, at 102.

40. See supra notes $21-26$ and accompanying text.

41. Langevoort, supra note 19 , at 716 n.143 ("Hopefully, the courts will recognize that where the bank itself securitizes some of its own loan portfolio, there is no overriding reason why it should not be able to shift the risk and return interest to individual investors . ...").

42. See Securities Indus. Ass'n v. Board of Governors, 468 U.S. 137, 181 (1984) (O'Connor, J., dissenting) ("Careful attention to the statutory language is especially important in an area as technical and complex as banking law, where the policies actually enacted into law are complicated and difficult for a nonspecialist judiciary to discern in their proper perspective.").

43. Cf. R. Bork, The antitrust Paradox (1978); R. Posner, Antitrust Law: An EcoNOMIC PERSPECTIVE (1976) (both arguing that courts have failed to properly analyze economic issues raised in antitrust cases). 
ing" as those terms are used in Glass-Steagall."4 This rationale provides the basis for expanding application of the transparency theory to allow banks to securitize and sell their other assets as well. ${ }^{45}$ To ensure that banks do not use their increased powers to purchase loans or other assets from third parties and immediately securitize and sell them, a meaningful definition of what constitutes the bank's own assets for purposes of securitization is needed. Adoption of the definition proposed in this Note will prevent banks from making a de facto entrance into the generally prohibited business of underwriting and dealing in securities for third parties.

\section{A. Assets Eligible for Securitization}

Expanding the scope of the transparency theory would permit banks to enhance the liquidity of their assets. ${ }^{16}$ This would provide banks with increased opportunity to remove higher-risk assets from their balance sheets. ${ }^{47}$ Moreover, as will be shown in Section IV, an expansion in this

44. Clarke Letter, supra note 28 , at 6 .

45. The transparency theory could be extended to permit banks to become involved in even greater securities powers. For example, the theory could be used to permit banks to underwrite and deal in instruments of other banks that are backed by "bank-eligible" securities. Such underwriting and dealing would not differ from the activities that section 16 of Glass-Steagall explicitly permits. See supra note 3 . The risk involved in underwriting and dealing in a security backed by a pool of GNMA certificates surely would not be greater than underwriting or dealing in the GNMA certificates themselves (which section 16 already permits).

The transparency theory could also be used to allow banks to offer mutual funds which are comprised solely of bank-eligible securities. Such funds are quite popular and could generate significant revenues without placing any bank capital at risk. See, e.g., Prudential-Bache GovernMent Plus Fund II, Prospectus 12 (Mar. 9, 1988) (listing Prudential-Bache's five mutual funds which invest primarily in U.S. Government securities, with total net assets exceeding $\$ 5.4$ billion as of Jan. 31 , 1988).

The Supreme Court refused to permit banks to operate open-end investment companies in Investment Co. Inst. v. Camp, 401 U.S. 617 (1971), because of concern that banks would become involved in the kind of promotional efforts that characterize the work of securities firms and which Congress sought to avoid. Id. at 630-34. Whatever merit this argument has in general, the Supreme Court's rationale in Camp is not applicable where only bank-eligible securities are involved. Since Congress has explicitly permitted banks to underwrite and deal in bank-eligible securities, it makes little sense to refuse to allow banks to offer mutual funds which are made up of these very same securities.

46. Pavel, supra note 16, at 16. Banks need liquidity to compete with non-bank institutions and foreign banks. See Corrigan, Financial Market Structure: A Longer View, 72 FED. RESERve BanK OF N.Y. ANN. REP. 12 (1987) ("The efficient working of a large modern economy clearly requires the presence of a stock of assets which are highly liquid and readily transferable. . . .").

47. Drexel, Burnham, Lambert \& Co. has designed a plan for banks to package and sell their nonperforming loans at a large discount. Apcar, Banks Increasingly Sell Parts of Their Loan Portfolio, Wall St. J., March 4, 1987, at 14, col. 1. Because of the time value of money, banks would be willing to accept a lesser amount for bad loans today rather than wait years to recover a greater percentage of the loans, since the price received for the loans could be reinvested in more promising lending activities. $I d$.

Virtually all loans that have been securitized to date, however, have been of high quality. Lowell Bryan, a director of McKinsey \& Co., argues that low-quality loans cannot be efficiently securitized under the current bank regulatory regime. See Bryan, The Credit Bomb in Our Financial System, HaRv. Bus. REv., Jan.-Feb. 1987, at 45, 49. Under the current regime, deposit insurance premiums and capital requirements do not take account of the riskiness of a bank's loan portfolio. Banks, therefore, have no real incentive to sell high-risk loans if their expected loss exceeds the capital that banks are required by regulators to keep on hand in case the loans become nonperforming.

There has long been discussion about the need for risk-based deposit insurance and capital require- 
manner would not give rise to any of the dangers that Glass-Steagall was enacted to avoid. Banks should be permitted to securitize any of their assets, regardless of their underlying risk. ${ }^{48}$

\section{High-Quality Assets}

The transparency theory should be expanded to permit banks to securitize such low-risk assets as: automobile loans; credit card receivables; and high-quality commercial loans. Automobile loans were first packaged and sold as securities by investment banks in $1985^{49}$ These securities, known as "certificate of automobile receivables" (CARs), are pass-through securities in which the interest and principal of the underlying auto loans are passed on to the security holders. The first public offering of CARs took place in March 1985, when Salomon Brothers offered $\$ 60$ million of passthrough securities backed by automobile loans originated and serviced by Marine Midland Bank. ${ }^{\text {so }}$

The only difference between CARs and mortgage-backed securities is the nature of the underlying collateral. Auto loans require more monitoring than loans secured by real property ${ }^{51}$ and therefore generally require higher servicing fees. This difference, however, is not relevant under the transparency theory, which is primarily concerned with allowing banks to securitize and sell assets that they can otherwise sell through more con-

ments. See, e.g., Scott \& Mayer, Risk and Regulation in Banking: Some Proposals for Federal Deposit Insurance Reform, 23 STAN. L. REv. 857 (1971). The Federal bank regulatory agencies have recently recommended adoption of a system of risk-based capital requirements developed by representatives of the bank regulatory authorities of Belgium, Canada, France, Germany, Italy, Japan, the Netherlands, Sweden, the United Kingdom, the United States, Switzerland, and Luxembourg. RiskBased Capital Guidelines, 53 Fed. Reg. 8549 (1988) (to be codified at 12 G.F.R. pts. 3, 225, 325) (proposed Mar. 15, 1988). The proposal advocates the use of a weighting system under which a bank's assets and off-balance sheet items (such as letters of credit) would be classified into five risk categories according to the credit risk of the obligor. Id. at 8552 . These categories primarily distinguish between United States Government securities, which are assigned to the lower risk categories, and loans to private borrowers, which are assigned to the highest risk category. Id. at 8557-59.

The major obstacle to implementing a more refined risk-based system is, of course, the inability to accurately quantify the risk of particular loans. If most bank assets were securitized, the market value of those assets and their corresponding risk could be determined. Pavel, supra note 16, at 24. If, however, banks guarantee the principal and interest on their securitized assets, and if the FDIC pays the holders of any such guarantees made by failed banks, the FDIC would be indirectly guaranteeing the securities. Such indirect guarantees would be taken into account in pricing the securities and would force regulators to value the FDIC's indirect guarantees in order to determine accurately the riskiness of a bank's loan portfolio. Id. Unfortunately, valuing these guarantees would be quite difficult, inhibiting the ability of regulators to implement effectively a system of risk-based deposit insurance and capital requirements.

48. Section 21 of Glass-Steagall contains explicit language in support of allowing banks to sell mortgage loans freely. See supra note 38 . While explicit statutory language supporting a bank's ability to sell these other underlying assets would provide further support for a decision to allow banks to underwrite and deal in securities backed by these assets, it is certainiy not a prerequisite to such a decision.

49. Pavel, supra note 16 , at 19 .

50. Id. at $19-20$.

51. A car is not stationary and does not maintain its value as well as a home. It therefore requires greater effort to monitor an automobile than a fixed, more permanent structure such as a house. 
ventional means. Banks are already permitted to buy and sell car loans, and, as long as there are adequate regulatory controls in place to protect against abuse of fiduciary duties, ${ }^{\mathrm{b2}}$ biased investment counseling, ${ }^{\mathrm{bs}}$ and tying, ${ }^{54}$ banks should be permitted to securitize these loans as well.

In April 1986, Salomon Brothers privately placed $\$ 50$ million of passthrough certificates backed by a pool of credit card receivables owned by Bank One of Columbus, Ohio. ${ }^{\mathrm{sS}}$ These receivables represent debts owed by holders of credit cards issued by the bank. As with mortgages and car loans, banks can freely sell their credit card receivables. An investor who purchases a security backed by a pool of these receivables obtains the same interest as if she had purchased the underlying receivables themselves. As long as adequate regulatory controls are in place to protect investors, allowing banks to underwrite and deal in securities backed by their credit card receivables would not raise any of the concerns which underlie GlassSteagall.

The transparency theory should also be expanded to permit banks to securitize and sell their low-risk commercial loans. Banks often sell such loans, and as long as adequate controls exist to protect the investing public from abuse, the Glass-Steagall Act should be interpreted to allow banks the opportunity to securitize them. To date, commercial loans have rarely been securitized. Because such loans are less homogeneous than automobile loans and credit card receivables, their securitization is more difficult. $^{\text {se }}$ In addition, banks have a number of alternatives to securitization, such as whole loan sales, participations, and syndications. ${ }^{37}$

\section{Low-Quality Assets}

Many banks currently find themselves holding high-risk assets as a result of aggressive lending to farmers, oil companies, real estate developers, and Third World nations. ${ }^{88}$ Allowing banks to underwrite securities backed by these loans would provide banks with an immediate source of

52. See infra notes $82-90$ and accompanying text.

53. See infra notes $91-98$ and accompanying text.

54. See infra notes 99-102.

55. Pavel, supra note 16 , at 21 . These certificates, called "certificates of amortizing revolving debts" (CARDs) have a stated maturity date of five years. For the first 18 months, certificate holders receive only the interest payment made on the receivables. Principal payments made during this time are used to purchase additional receivables. Following the first 18 months, investors receive principal payments.

56. Commercial loans have widely varying terms to maturity, pricing, and timing of payments. Pavel, supra note 17, at 25. Commercial loans guaranteed by the Small Business Administration (SBA), however, have been securitized, because they are more uniform and much of the risk is assumed by the federal government. Id.

57. Id.

58. See, e.g., Bock, supra note 9, at 60; Berg, Three Major Banks Post Big Losses, N.Y. Times, July 22, 1987, at D1, col. 6; Schmitt \& Hill, Banks to Post Record $\$ 10$ Billion Loss for 2nd Quarter, Wall St. J., July 20, 1987, at 2, col. 1 . 
funds that could be allocated to more promising lending activities. ${ }^{60}$ Such securitization would permit banks to offer investors a diversified mix of loans that would command a higher return than if the loans were sold on a piecemeal basis. ${ }^{80}$ As is the case with other high-risk securities (like junk bonds), the antifraud and disclosure provisions of the securities laws would provide sufficient protection for investors who might purchase a security made up of these problem loans. ${ }^{81}$

\section{B. Ensuring that Banks Do Not Liberalize the Definition of "Assets" to Exploit the Transparency Theory}

The Glass-Steagall Act generally prohibits banks from underwriting securities for third parties. ${ }^{82}$ Thus, before courts and bank regulators expand the transparency theory, a precise definition of "bank assets eligible for securitization" is needed to prevent a bank from purchasing loans from third parties (so that the loans would then be considered part of the bank's own assets) and immediately securitizing and selling them to investors at a profit. This problem of potential abuse can be minimized by defining "bank assets eligible for securitization" as assets that are held for investment, rather than trading, purposes. A loan bought with the sole or primary intent of securitizing and selling it for short-term profit would be treated as having been purchased for trading purposes. On the other hand, a bank that purchases a loan with the intention of servicing and accounting for the loan as part of its own portfolio, thinking that it could do so more profitably than the originating bank (e.g., because of economies of scale enjoyed by the purchasing bank in servicing a particular type of loan), would be considered to have bought the loan for investment purposes.

Bank examiners could be entrusted with the task of ensuring that banks are securitizing only assets that they originated or assets purchased for investment purposes. In determining whether an asset is appropriately characterized as being held for investment purposes, bank examiners would perform the following procedures: (1) review internal bank memoranda and minutes of Board of Directors' meetings; (2) conduct interviews with key bank personnel; (3) review the elapsed time between asset acquisition and securitization and sale; and (4) review the bank's current and historical activity in transactions similar to those at issue. Bank manage-

59. See supra note 47 for the conflicting views as to the feasibility of securitizing nonperforming loans under the current system of deposit insurance and capital requirements which do not take account of the riskiness of a bank's loan portfolio.

60. For example, loans from Third World nations could be packaged in order to achieve geographic diversity, so that loans from volatile regions are mixed with loans from more stable areas. In addition, loans made to public entities could be mixed with loans to private entities to enable investors to further diversify their risk.

61. See infra notes $95-98$ and accompanying text.

62. See supra text accompanying notes 35-38. 
ment should be required to report to the Board of Directors the purpose behind any acquisition of loans from another bank.

If it were discovered that loans were purchased and immediately securitized in violation of Glass-Steagall, bank examiners could terminate the activity under its statutory authority to eliminate "unsafe or unsound" practices. $^{63}$ The regulatory agencies could also assess civil fines ${ }^{64}$ or remove the directors or officers responsible for the illegal sales. ${ }^{65}$

Bank examiners already play a similar oversight role in another context. Under the current regulatory system, a bank is allowed to trade on its own account in certain approved securities. A bank's trading inventory of securities must be accounted for at market value or at the lower of cost or market value, whichever method it uses for tax purposes. ${ }^{86}$ In contrast, a bank may account for securities which it purchases for investment purposes, such as for its trust accounts, using the historical cost method. ${ }^{87}$ Bank examiners are charged with the responsibility of investigating a bank's characterization of its securities activities. Such examiners are given the power to issue cease and desist orders, assess civil monetary penalties, and remove those directors and officers who commingle securities purchased for trading purposes and securities bought for investment purposes.

\section{Protecting Against Conflicts of Interest and Threats to BANK SAFETy and SoUndNESS}

The primary purpose of the Glass-Steagall Act was to ensure that banks would not divert funds from traditional, productive uses to more speculative endeavors. ${ }^{68}$ Concern with conflicts of interest and other soundness problems that could arise from bank involvement in securities underwriting or dealing were ancillary to that objective. ${ }^{69}$ These ancillary concerns can be adequately protected against through regulation. GlassSteagall's prohibitory language only refers to its primary concern-preventing banks from using depositor funds for speculative purposes.

This Section will show that the concerns about conflicts of interest and bank safety that could arise if banks were permitted to securitize and sell

\footnotetext{
63. 12 U.S.C. $\S 1818(a)$, (b) (1982).

64. Id. \& $1818(\mathrm{i})$.

65. Id. § $1818(\mathrm{e})$.

66. See Financial Instrtutions Examination Council, Instructions for Preparation of Reports of Condition and Income for a Bank with Domestic Offices OnLy and ToTAL ASSETS OF $\$ 300$ Million OR MORE RC-2, A-37 (1987).

67. Under the historical cost approach, a security owned by a bank is valued on the bank's financial statements at its purchase price. The lower of cost or market approach, on the other hand, forces a bank to reduce the reported value of a security whenever the market price falls below its purchase price.

68. See supra notes $21-23$ and accompanying text.

69. See supra note 26 and accompanying text.
} 
their own assets would be adequately controlled by the current regulatory system. This system has been strengthened substantially since the enactment of Glass-Steagall, and further strengthening of the regulatory system could provide additional protection.

\section{A. Conflicts of Interest}

Permitting banks to securitize and sell their own assets could create perverse incentives for banks to: (1) enter into unfavorable loan and securities transactions in order to ensure the success of their securities departments; (2) finance investor purchases of issues underwritten by their securities departments; (3) fail to maintain independence in exercising their fiduciary duties; (4) fail to render sound, objective investment advice; and (5) "tie" the extension of credit to the purchase of some of their securitized assets. ${ }^{70}$ As the analysis below indicates, these conflicts of interest can be adequately controlled through regulation of the securitization process.

In addition to legal regulation, three other factors may help prevent banks from exploiting conflicts of interest: (1) the market for corporate control, through which mismanaged banks (whose stock is undervalued) could be taken over by investors who could then replace current management with a more prudent group; ${ }^{71}$ (2) the concern with maintaining a favorable reputation in the financial markets, which may constrain risky behavior by banks concerned with their continued ability to obtain funds for lending activities; ${ }^{72}$ and (3) the monitoring activities of bank regula-

70. See Kelly, supra note 18 , at 233-35.

71. See Easterbrook \& Fischel, The Proper Role of a Target's Management in Responding to a Tender Offer, 94 HARv. L. Rev. 1161, 1169-74 (1981); Romano, Law as a Product: Some Pieces of the Incorporation Puzzle, 1 J.L. EcoN. \& ORG. 225, 229-30 (1985); Winter, State Law, Shareholder Protection, and the Theory of the Corporation, J. LEGAl STuD. 251, 264-66 (1977). Under current law, commercial firms and banks cannot have common ownership. 12 U.S.C. $\$ 1843$ (a) (1982). Banks, however, are susceptible to takeover attempts by individual investor groups or by other banks.

72. See, e.g., Gilson \& Kraakman, The Mechanisms of Market Efficiency, 70 VA. L. REv. 549, 619 (1984); Kraakman, Gatekeepers: The Anatomy of a Third-Party Enforcement Strategy, 2 J.L. ECON. \& ORG. 53, 93-94 (1986). A debate has arisen over the extent to which depositors can and do control bank risk-taking. Professor Garten argues that most uninsured depositors (the only depositors with any incentive to monitor bank risk) do not vigilantly monitor bank management and that depositors generally rely on the liquidity of their investments, rather than on an analysis of bank financial reports, to protect themselves against risk of loss. Garten, Still Banking on the Market: A Comment on the Failure of Market Discipline, 5 YALE J. ON REG. 241, 241-42 (1988). Such depositors simply withdraw their money from a bank at the first sign of trouble instead of monitoring bank risk and exerting pressure on management to reduce such risk. Id. at 243.

Professor Macey and Elizabeth Garrett, on the other hand, argue that empirical studies demonstrate that depositors do exert some control on bank risk-taking and that the bank regulatory system should be modified to increase the incentive of depositors to monitor bank risk with greater vigilance. Macey \& Garrett, Market Discipline by Depositors: A Summary of the Theoretical and Empirical Arguments, 5 YALE J. ON REg. 215, 233-37 (1988) (suggesting a move to risk-related deposit insurance and adoption of a modified payout procedure by the FDIC to expose uninsured depositors to the risk of loss in the event of a bank failure). 
tors, which should constrain even those desperate, failing banks that are no longer concerned with maintaining a favorable reputation. ${ }^{73}$

\section{Ill-advised Loan and Securities Transactions}

Allowing a bank to engage in securities activities might lead the bank to enter into unfavorable loan and securities transactions to ensure the success of its securities department. ${ }^{74}$ Thus, it is feared that a bank would lend more freely to its own securities department than it would to outside borrowers. Concern has also been expressed that a bank would purchase securities (for its trust accounts or for its own trading or investment portfolio) which its securities department had been unable to sell. ${ }^{25}$ This concern would be relevant if the bank's securities department involved itself in the speculative securities of third parties so as to threaten the welfare of depositors or shareholders. Allowing a bank to securitize and sell its own assets, however, would not present any new threats to depositors or shareholders, since they are already exposed to the risks associated with the underlying assets to be securitized. In fact, if anything, allowing such securitization helps protect their interests, because this activity gives the bank broader opportunity to sell problem assets at a more attractive price. $^{\text {36 }}$

It could be argued that allowing banks this flexibility in selling their assets gives them a dangerous incentive to engage in high-risk lending to the detriment of depositors or shareholders. The primary incomeproducing activity of banks, however, is lending. In order to maximize profits, banks must assemble strong, diversified loan portfolios. The market for corporate control should help to prevent bank officers from making reckless loan decisions, since the market price of the shares of stock of a bank that is not being run efficiently will decline and the bank will then become an attractive takeover candidate. ${ }^{77}$

While allowing banks to securitize and sell their loans and other assets

73. Examiners use a composite rating system, with five categories, to assess the financial condition of banks. Bank regulators pay special attention to institutions that receive ratings in the weakest three categories. See Federal Financial Institutions Examination Council, Uniform Financial Rating System, [1979-1980 Transfer Binder] Fed. Banking L. Rep. (CCH) โ98,110 (Nov. 21, 1979); see also E. Symons \& J. White, Banking Law 572-74 (2d ed. 1984). Thus, examiners could focus particular attention on preventing the management of a failing bank from securitizing and selling all of the bank's high-quality assets, embezzling the proceeds, and leaving only the nonperforming loans to satisfy the claims of depositors and shareholders.

74. Kelly, supra note 18, at 233.

75. Id.

76. See supra note 47 for a discussion of the conflicting views as to the feasibility of securitizing and selling high-risk assets under the current system of deposit insurance and capital requirements, which does not take into account the riskiness of a bank's loan portfolio.

77. See supra note 71 and accompanying text. It is possible that, rather than respond to the market for corporate control by reducing risk, bank management might continue its risky activity and merely shift such risk to depositors or to the FDIC. Concern with maintaining a favorable reputation among depositors and monitoring by bank examiners, however, should help to discourage banks from taking excessive risks. See supra notes $72-73$ and accompanying text. 
promotes liquidity, the price that investors pay for such securities will be inversely related to the riskiness of the underlying assets. ${ }^{78}$ Securitization only facilitates the saleability of bank assets; it does not guarantee a specified price from investors. Thus, a profit-maximizing bank, in making lending decisions, will not disregard risk considerations just because it is confident that it can securitize and sell any loans that later turn out to be bad.

\section{Imprudent Loans to Finance the Distribution of Securities}

Some have asserted that permitting banks greater securities powers could lead them to lend more freely to investors who plan to purchase issues underwritten by their own securities department. ${ }^{79}$ According to this scenario, banks would finance purchases of securities that they would otherwise not finance if the securities purchased were not issued by the banks' own securities departments. A bank, however, would have no economic incentive to engage in this kind of financing. The bank gains nothing by making a loan that it would not otherwise make in order to support the purchase of a high-risk security issued by its securities department. Once the securities department decides to underwrite or deal in a security, the bank bears the risks associated with holding that instrument. If a bank lends money to a third party on the basis of this security to support the bank's securities department, the bank's loan department assumes these risks. Thus, such a loan transaction would merely shift the bank's risks associated with the security from its securities department to its loan department and would not benefit the bank.

Even if this conflict were perceived as a problem, regulation could adequately protect against abuses. Restrictions could be imposed on the amount that a bank could loan to a customer to purchase a bank's own securities issuances. ${ }^{80}$ In addition, Section 11(d)(1) of the Exchange Act of $1934^{81}$ could be used to prohibit a bank's securities department from directly or indirectly arranging for the extension of credit to a customer on any security in the distribution of which the department participated within 30 days prior to such credit extension.

\section{The Independence of Bank Fiduciary Activities}

A bank's involvement in securities underwriting, it is argued, could affect the independent exercise of its fiduciary duties. For example, a bank

78. See Pavel, supra note 16, at 24 ("The riskiness of a loan-backed security is the main determinant of its price. The riskier the security, the lower the price, and the higher the yield."). This is, of course, why junk bonds and other instruments of companies with low credit ratings have such high yields.

79. Kelly, supra note 18 , at $233-34$.

80. Id. at 238 .

81. 15 U.S.C. $\S 78 k(d)(1)$ (1982). 
might sell to customers of its trust department securities that it is underwriting and having difficulty selling. ${ }^{82}$ While a bank could securitize some of its high-risk assets and sell them to its own trust accounts, legal rules are already in place to protect against such a possibility. The common law has long prohibited self-dealing by a trustee. ${ }^{83}$ The common law rules against self-dealing are liberally supplemented by statute and regulation. Some states have enacted legislation prohibiting self-dealing by statechartered bank trustees. ${ }^{84}$ The Employee Retirement Income Security Act of 1974 (ERISA) imposes severe penalties on pension plan trustees (a role in which bank trust departments often serve) who engage in self-dealing. ${ }^{85}$ The OCC has also promulgated regulations which prohibit self-dealing. ${ }^{88}$

This conflict of interest has long existed for securities firms and even for banks. ${ }^{87}$ Securities firms provide investment advice in addition to underwriting and dealing in securities. Similarly, banks have long been allowed to underwrite and deal in United States Government and municipal securities in addition to performing their banking and fiduciary functions. $^{88}$ The existing legal rules appear to have effectively prevented abuses by securities firms and banks. A 1975 Treasury Department study noted that it had no record of any exploitation of conflicts by banks in forty years of underwriting general obligation municipal bonds. ${ }^{88}$ A 1977 Federal Reserve Board study of private placement activities of commercial banks also failed to uncover any abuses. ${ }^{90}$

\section{Inability to Provide Disinterested Investment Advice}

Some commentators have argued that a bank will be unable to render sound, objective investment advice if it has a promotional stake in certain securities. ${ }^{.1}$ Securities firms, however, have long been permitted to underwrite, trade, and even maintain markets in securities and, at the same time, render investment advice. Moreover, banks already engage in a significant amount of underwriting of, and dealing in, United States Government and municipal securities. A bank, therefore, already has a strong incentive to encourage investors to purchase the securities that the bank has underwritten or is dealing in, since the bank has a substantial stake in

82. Kelly, supra note 18 , at 233.

83. See, e.g., G. BogerT, Trusts $\$ 95$ (6th ed. 1987).

84. See, e.g., N.Y. Banking Law § 100-b, subd. 1 (McKinney 1971); 7 Pa. Cons. Stat. Ann.

$\S 403$ (h) (Purdon 1967); Iowa CoDE ANN. $\S 524.1002(5)$ (West 1970).

85. 29 U.S.C. $\S 1106$ (1982); 26 U.S.C. $\$ 4975$ (1982).

86. 12 C.F.R. $\$ 9.12(a)$ (1987).

87. See Kelly, supra note 18 , at 237.

88. See supra note 3 (discussing bank-eligible securities).

89. U.S. Dep't of Treasury, Public Policy Aspects of Bank Securities Activities 35 n.41 (1975), cited in Kelly, supra note 18, at 237.

90. Federal Reserve Board, Commercial Bank Private Placement activities 65 (1977), cited in Kelly, supra note 18, at 237.

91. Kelly, supra note 18 , at 234 . 
the performance of such securities. ${ }^{92}$ When engaged in either underwriting or dealing, the bank bears the risk that it will not be able to resell these securities at a profit, just as it bears the risk that any of its other assets will decline in value. Thus, permitting a bank the additional securities powers suggested in this paper would not provide any greater incentive for the bank to provide biased investment advice than already exists in the case of government securities in which the bank has an ownership interest.

Nevertheless, if this conflict were perceived as a problem, regulatory action could be taken to prevent abuses. For example, banks could be prevented from distributing to depositors promotional information regarding securities issuances. ${ }^{93}$ The Federal Reserve Board already prohibits bank holding companies from making promotional information available to the public at any office of the holding company. ${ }^{\text {at }}$ Similar regulations could be implemented for non-member banks. In addition, the securities laws (including the disclosure requirements $\mathrm{s}^{95}$ and the antifraud provisions $\mathrm{s}^{96}$ ) and the Investment Advisers Act ${ }^{97}$ could be made applicable to banks in order to prevent abuses. ${ }^{98}$

\section{Tying the Extension of Credit to the Purchase of Securities}

Opponents of increased bank securities powers have also argued that a bank might attempt to "tie" the extension of credit to the purchase of securities issued by the bank's securities department. ${ }^{98}$ To obtain credit, a customer would have to agree to purchase the securities. The antitrust laws are designed to prevent this sort of tying arrangement. ${ }^{100}$ In addition, Section 106(b) of the Bank Holding Company Act Amendments of $1970^{101}$ prohibits most tying arrangements. Moreover, given the available substitutes for almost all banking services and the increasing geographic reach of credit markets, banks would lack the market power to carry out a tying arrangement. ${ }^{102}$

92. See Fischel, Rosenfield \& Stillman, The Regulation of Banks and Bank Holding Companies, 73 VA. L. REv. 301, 325 (1987). In fact, it could be argued that bank investment advice would be more objective if banks could engage in a broader range of financial services. Id.

93. Kelly, supra note 18 , at 239 .

94. 12 C.F.R. $\$ 225.125$ (h) (1987). The Supreme Court upheld the validity of these regulations in Board of Governors v. Investment Co. Inst., 450 U.S. 46 (1981).

95. See, e.g., 15 U.S.C. $\$ \S 77 \mathrm{~g}, 77 \mathrm{j}, 77 \mathrm{aa}(1982)$.

96. $I d . \S 77 \mathrm{q}(1982)$.

97. Id. $\S \S 80 \mathrm{~b}-1$ to $80 \mathrm{~b}-21$ (1982).

98. Except for the antifraud provisions, the Securities Act of 1933 does not currently apply to banks. Id. $\$ 77 \mathrm{c}(\mathrm{a})(2)(1982)$. A number of the antifraud provisions of the Securities Exchange Act of 1934 also do not apply to banks. Id. $\S 78 \mathrm{c}(2)(4)$. In addition, the Investment Advisers Act escludes banks from its coverage. Id.

99. See Kelly, supra note 18, at 234.

100. Id. at 241.

101. 12 U.S.C. $\$ 1972$ (1982).

102. See Fischel, Rosenfield, \& Stillman, supra note 92, at 329. A bank might try to induce an unwitting borrower into believing that the bank has such market power. Competition among financial 


\section{B. Safety and Soundness}

In addition to preventing the conflicts of interest discussed above, another ancillary purpose of the Glass-Steagall Act is to maintain public confidence in the safety and soundness of the commercial banking system. ${ }^{103}$ Congress was concerned that bank involvement in securities underwriting or dealing would lead to a loss of public confidence in the banking system, causing depositors to withdraw their funds and, in turn, resulting in widespread bank failures. ${ }^{104}$ Most bank failures, however, are attributable to unwise loans and/or imprudent management rather than to involvement in non-traditional activities. ${ }^{105} \mathrm{~A}$ study examining all 120 commercial bank failures between 1971 and 1982 revealed that only one bank failed because of its involvement in non-banking activities. ${ }^{108}$ Moreover, other empirical studies suggest that activity diversification by banks can actually reduce the volatility of bank performance. ${ }^{107}$

Legislators and bank regulators generally believe that non-traditional activities should be confined to separate subsidiaries of bank holding companies rather than allowing the banks themselves to engage in these activities. ${ }^{108}$ Professor Clark notes that the fundamental reason for organizing the non-traditional activities separately is to ease the regulator's job of monitoring the safety and soundness of the banking system. ${ }^{109}$ As discussed above, however, permitting banks to securitize and sell their assets would not threaten the stability of the financial system. Moreover, it is far from obvious that those activities which banks are currently engaged in, such as trading foreign currencies, lending to Third World nations, or underwriting and dealing in government securities, present any less of a problem for regulators in assessing bank soundness than would the securitization and sale of bank assets. ${ }^{110}$ In practice, banks might not be truly insulated if a separately incorporated non-banking affiliate experienced financial difficulties. ${ }^{111}$ Thus, few benefits are likely to accrue from re-

services firms, however, should ensure that debtors are adequately informed about the alternative financing sources available.

103. See Langevoort, supra note 19 , at $699,714$.

104. See Note, Conduct-Oriented Approach, supra note 18, at 106 ("Congress was convinced that banks' speculative securities promotion and perilous underwriting activities led to the loss of depositor confidence and customer good will that caused the depression era bank runs.")

105. Saunders, Bank Safety and Soundness and the Risks of Corporate Securities Activities, in Deregulating Wall Street, supra note 14 , at 181 .

106. Id. at 181-82.

107. Id. at 176-77. Expanding the transparency theory even further to permit banks to underwrite and deal in instruments of other banks backed by bank-eligible securities and to offer mutual funds comprised solely of bank-cligible securities, see supra note 43 , would, therefore, likely increase the banking system's stability.

108. R. LrTAN, supra note 14 , at 145.

109. Clark, The Regulation of Financial Holding Companies, 92 HARv. L. REv. 787, 815 (1979).

110. See Fischel, Rosenfield \& Stillman, supra note 92, at 321.

111. See R. LITAN, supra note 14, at 146 ("[T] There is evidence that banks will find ways of assisting their nonbanking affiliates if these affiliates encounter financial trouble."). In fact, Continen- 
quiring the securitization and sale of bank assets to be conducted within separately capitalized affiliates. ${ }^{112}$

\section{Conclusion}

The financial markets have changed substantially in recent years. Banks have lost many of their safest lending opportunities to underwriters of commercial paper, and competition from money market mutual funds has increased the interest rates that banks must pay to attract deposits. Hopefully, Congress will repeal Glass-Steagall and permit bank holding companies to engage in a full range of securities activities. Until this occurs, however, courts and bank regulators should use the transparency theory to permit banks the securities powers advocated in this Note. This would provide significant opportunities to improve the financial position of banks without raising any of the concerns which underlie GlassSteagall.

tal Illinois Bank was recently found to have violated lending limits in loans made to First Options of Chicago, a non-banking subsidiary of Continental's parent holding company. See Povich, supra note 16.

112. This Note recognizes that confining non-traditional activities to separate affiliates would prevent banks from using federally insured deposits to fund such activities. Since the FDIC does not guarantee repayment of money invested in non-banks, this would ensure that banks do not gain an unfair advantage over non-banks in competing for the business of third parties. See R. LIrAN, supra note 14 , at 146 . Non-banks would not be affected, however, when banks merely securitized and sold their own assets. Banks would not pay a non-bank to securitize their assets if they had the power to do so themselves or to do so through non-subsidized affiliates. 